\title{
The Cytoprotective Effect of Amifostine Against Radiation Induced Toxicity
}

\author{
Vassilis E. Kouloulias ${ }^{1}$ and John R. Kouvaris ${ }^{2}$ \\ ${ }^{1}$ Attikon Hospital University of Athens, Medical School, \\ ${ }^{2}$ Aretaieion Hospital University of Athens, Medical School, Athens,
}

Greece

\section{Introduction}

Radiation treatment is an important therapeutic option for a number of malignancies (American Cancer Society), but its use is frequently limited by adverse effects on normal tissues (Stone et al., 2003). Thus, the goal of most oncology treatments is to maximize the antineoplastic effect while minimizing deleterious outcomes for the patient. WR-2721 was developed by the U.S. Army Anti-Radiation Drug Development Program for its potential to protect against damage caused by ionizing radiation (Yuhas \&Stoner, 1969). Today, WR2721 is known as amifostine (Ethyol ${ }^{\circledR}$; MedImmune Oncology, Inc., Gaithersburg, MD). Initial preclinical studies demonstrated that amifostine could protect treated mice from lethal doses of radiation, and this protection did not extend to transplanted mammary tumor cells (Yuhas \&Stoner, 1969).

Amifostine, a thiol that protects cells from damage by scavenging oxygen-derived free radicals, was later evaluated for a potential role in reducing the toxicities from radiation and chemotherapeutic agents, such as alkylating agents and platinum agents. In contrast to organspecific protectants, amifostine is considered a broad-spectrum cytoprotective agent (Hensley et al., 1999). Preclinical studies demonstrated that amifostine can selectively protect almost all normal tissues from the cytotoxic effects of some chemotherapeutic agents and radiation therapy. Neoplastic tissues do not benefit from amifostine's protection (Koukourakis, 2003; Sasse et al., 2006; Yuhas et al., 1980). Amifostine is an inactive prodrug that cannot protect until dephosphorylated to the active metabolite, WR-1065, by alkaline phosphatase in the plasma membrane (Calabro-Jones et al., 1985). The selective protection of normal tissue is the result of a greater accumulation of WR-1065 in normal tissues than in tumor cells. Tumors are relatively hypovascular, thus resulting in comparative hypoxia and a low interstitial $\mathrm{pH}$. Furthermore, alkaline phosphatase expression is reduced in malignant tissues. Taken together, the combination of hypovascularity, low $\mathrm{pH}$, and reduced enzyme levels results in low accumulation of active drug in tumor tissues. Thus, normal tissues may be able to maintain as much as a 100-fold greater concentration of the free thiol than tumor tissue (Yuhas, 1980).

Once inside the cell, WR-1065 scavenges free radicals, protecting cellular membranes and DNA from damage. However, other studies have suggested that additional mechanisms may also play important roles in the action of amifostine. In vitro studies have shown that 
oxidation of WR-1065 to its polyamine-like disulfide metabolite (WR-33278) is followed by a rapid consumption of oxygen in culture medium, suggesting that induction of cellular anoxia may be a mechanism for radioprotection (Purdie et al., 1983). This was supported by a study by Glover et al. that showed a rapid increase in the oxygen saturation of the venous blood after i.v. administration of amifostine without affecting the oxygen dissociation curves of hemoglobin, again suggesting that a decrease in oxygen consumption by normal tissues may be involved in amifostine-related radioprotection (Glover et al., 1984). In another study, high concentrations of WR-33278 condensed DNA, thereby limiting potential target sites for free-radical attack (Savoye et al., 1997). This activity would clearly account for a decrease in the number of double-strand breaks after radiotherapy, in turn leading to a reduction of the transient block at the G2 phase of cell division induced by radiation (Rubin et al., 1996). The enhanced cellular proliferation that results from a reduction in damage to DNA may be an important pathway to accelerated recovery of endothelial tissues that are affected soon after radiation exposure (Rubin et al., 1996) and seems to be important for the recovery of irradiated mucosa (Koukourakis et al., 1999). In addition, amifostine, indirectly through hypoxia, may upregulate the expression of a variety of proteins involved with DNA repair and inhibition of apoptosis, such as Bcl-2 and hypoxia-inducible factor-1 (Carmeliet et al., 1998; Kajstura et al., 1996; Shimizu et al., 1996).

Early phase I trials with amifostine were not able to demonstrate a maximum-tolerated dose but did establish a tolerable dose range of $740-910 \mathrm{mg} / \mathrm{m} 2$ for use in phase II studies (Blumberg et al., 1982). Amifostine is generally well tolerated, although transient adverse events may be dose related and include hypotension, nausea, vomiting, sneezing, somnolence, a metallic taste during infusion, and occasional allergic reactions that may include rash, fever, and anaphylactic shock (Blumberg et al., 1982). Although hypotension is the most clinically significant adverse event, treatment interruptions caused by a significant decline in blood pressure are rare, occurring in $<5 \%$ of patients receiving amifostine. Emesis can be reduced with judicious use of an antiemetic regimen before amifostine administration. Transient hypocalcemia caused by inhibition of parathyroid hormone secretion has also been reported (Glover et al., 1983). The incidence and severity of amifostine-related adverse events have been shown to vary based on the route of administration. A recent meta-analysis of randomized studies using amifostine reported a significantly greater risk for grade 3 or 4 hypotension when amifostine was administered as a slow i.v. infusion (Sasse et al., 2006). Studies examining the s.c. administration of amifostine have demonstrated a lower incidence of hypotension and nausea/vomiting than with i.v. administration (Koukourakis et al., 2000; Anne \& Curran, 2002; Anne et al., 2007). However, s.c. administration of amifostine has been reported to be associated with a higher incidence of fever and cutaneous reactions than with i.v. administration in these studies (Sasse et al., 2006; Koukourakis et al., 2000; Anne \& Curran, 2002; Anne et al., 2007).

Pharmacokinetic studies in patients have demonstrated that amifostine is rapidly cleared from the plasma compartment, with a half-life of $<1$ minute, and $>90 \%$ cleared within 6 minutes (Shaw et al., 1986). However, very little amifostine, or the metabolites WR-1065 and WR-33278, is excreted in urine 1 hour after injection. These data show that once amifostine enters the plasma, it is rapidly metabolized and distributed in the tissues, whereas the excretion of the metabolic products is very slow. Timely administration of amifostine relative to radiation or chemotherapeutic treatment is necessary. One study by Buentzel et al., in which amifostine was administered 30 minutes before chemoradiotherapy, demonstrated no significant difference in the incidence of grade 2 acute or chronic 
xerostomia or grade 3 oral mucositis between patients receiving i.v. amifostine and those receiving placebo (Buentzel et al., 2006). On days when combined radiochemotherapy was administered, timing between amifostine and radiotherapy may have exceeded 60 minutes. The authors suggest that timing of the amifostine doses relative to the beginning of radiotherapy may have influenced efficacy because of inadequate exposure to amifostine. In addition, the observed rates of grade 2 acute xerostomia and grade 3 oral mucositis in the placebo group were unexpectedly low, reducing the ability of the study to show significant benefit with amifostine. In contrast, studies in which amifostine was administered within 30 minutes of radiotherapy have shown promise with regard to protection from acute and chronic xerostomia (Andonadou et al., 2002; Brizel et al., 2000; Vacha et al., 2003). Taken together, it appears that administration of amifostine within 30 minutes of radiotherapy or chemoradiotherapy may provide optimal benefit for cytoprotection of normal tissues.

Of primary concern with the use of any substance or technique that is intended to spare normal tissues from treatment-related toxicities is the unintended and undesirable protection of tumor cells. Clearly, procedures that protect tumors are not clinically useful. A recent meta-analysis of the available clinical data concluded that, in addition to reducing the toxicities associated with radiation therapy, amifostine does not affect the efficacy of radiotherapy (Sasse et al., 2006). To the contrary, patients receiving amifostine with radiotherapy achieved higher rates of complete response, presumably the result of fewer treatment interruptions because of reduced acute toxicity of the treatment.

\subsection{Xerostomia and oral mucositis}

Xerostomia and mucositis are significant and potentially debilitating toxicities associated with radiation therapy. The risk for these complications depends on the area receiving radiation, the dose and schedule of therapy, whether radiation therapy is combined with chemotherapy, and other factors (Sonis \& Fey, 2002). Although rarely life threatening, the acute and long-term consequences can be significant, causing discomfort, reduced nutrition, and a diminished quality of life. Xerostomia is the most common toxicity associated with standard fractionated radiation therapy to the head and neck. Whereas acute xerostomia from radiation is the result of an inflammatory reaction, late xerostomia, observed 1 year after radiation, is usually a permanent result of fibrosis of the salivary gland. The dry mouth of xerostomia affects the patient's ability to eat and speak. The decreased salivary output in patients with xerostomia can be responsible for an increased risk for dental caries, oral infections, and osteonecrosis.

The results of numerous randomized controlled studies suggest that amifostine may protect against radiation- and chemoradiation-induced toxicity in patients with head and neck cancer (Table 1) (Sasse et al., 2006). In one study by Buntzel et al., 28 patients received radiation therapy in conjunction with carboplatin (Buntzel et al., 1998). Amifostine was administered to 14 patients on the day of carboplatin at a fixed dose of $500 \mathrm{mg}$ (equivalent to $250-340 \mathrm{mg} / \mathrm{m} 2)$. Acute grade 3 or 4 mucositis was experienced by 12 of 14 patients $(86 \%)$ treated with radiochemotherapy alone compared with none of the amifostine-treated

patients $(\mathrm{p}<.001)$. Additionally, at a 12 -month follow-up, $17 \%$ of patients who received amifostine experienced late grade 2 xerostomia, compared with $55 \%$ of the patients treated without amifostine $(p=.05)$. An international phase III trial of radiation therapy with and without amifostine was conducted in 315 patients with squamous cell carcinoma of the head 


\begin{tabular}{|c|c|c|c|}
\hline Study & $\begin{array}{l}\text { Number } \\
\text { of patients }\end{array}$ & Treatment & Main conclusions \\
\hline \multicolumn{4}{|l|}{ RT } \\
\hline McDonald et at., 1994 & 9 & $\begin{array}{l}\text { RT + i.v, amifostine, } \\
100 \mathrm{mg} / \mathrm{m}^{2}\end{array}$ & $\begin{array}{l}\text { Flow rates of unstimulated whole } \\
\text { saliva recovered to } 20 \% \text { of baseline at } \\
12 \text { months post-treatment }\end{array}$ \\
\hline Wagner etal., 1998 & 14 & $\begin{array}{l}\text { RT } 4 \cdot \text { i.v. } \\
\text { amifostine. } 200 \\
\mathrm{mg} / \mathrm{m}^{2}\end{array}$ & $\begin{array}{l}\text { i.v. amifostine treatment led to } \\
\text { significant reduction in oral } \\
\text { symptoms and duration of mucositis }\end{array}$ \\
\hline Bourhis et al., 2000 & 26 & $\begin{array}{l}\text { RT }+ \text { i.v. amifostine, } \\
150 \mathrm{mg} / \mathrm{m}^{2} \text {, versus } \\
\text { RT alone }\end{array}$ & $\begin{array}{l}\text { iv. amifostine treatment led to } \\
\text { significant reduction in duration of } \\
\text { acute mucositis and duration of } \\
\text { feeding tube use compared with RT } \\
\text { treatment alone }\end{array}$ \\
\hline Koukourakis et al., 2000 & 40 & $\begin{array}{l}\text { RT + s.c. amifostine, } \\
500 \mathrm{mg} \text {, versus } \mathrm{RT} \\
\text { alone }\end{array}$ & $\begin{array}{l}\text { s.c. amifostine led to significant } \\
\text { reduction in severity of oral mucositis } \\
\text { compared with RT treatment alone }\end{array}$ \\
\hline Brizel et al., 2000 & 315 & $\begin{array}{l}\text { RT }+ \text { i.v. amifostine, } \\
200 \mathrm{mg} / \mathrm{m}^{2} \text {, versus } \\
\text { RT alone }\end{array}$ & $\begin{array}{l}\text { i.v. amifostine led to significant } \\
\text { reduction inacute and chronic } \\
\text { xerostomia versus RT alone and } \\
\text { increased saliva production versus RT } \\
\text { alone; no significant reduction in } \\
\text { grade } \geq 3 \text { mucositis versus RT }\end{array}$ \\
\hline Wasserman et al., 2005 & 315 & $\begin{array}{l}\text { 2-yr follow-up of } \\
\text { Brizel etal. (2000) } \\
{[26]}\end{array}$ & $\begin{array}{l}\text { i.v. amifostine led to significant } \\
\text { decrease in severity and duration of } \\
\text { xerostomia at } 2 \text { yrs post-treatment } \\
\text { without compromising tumor control }\end{array}$ \\
\hline Anne el al., 2002, 2007 & 54 & $\begin{array}{l}\text { RT + s.c. amifostine, } \\
500 \mathrm{mg}\end{array}$ & $\begin{array}{l}\text { Incidence of acute grade } \geq 2 \\
\text { xerostomia, } 56 \% ; 1-\mathrm{yr} \text { rates of } \\
\text { locoregional tumor control, } \\
\text { progression-free survival, and overall } \\
\text { survival, } 78 \%, 75 \% \text {, and } 85 \% \text {, } \\
\text { respectively }\end{array}$ \\
\hline \multicolumn{4}{|l|}{ RCT } \\
\hline Buntzel et al., 1998 & 39 & $\begin{array}{l}\text { RT }+ \text { carboplatin }+ \\
\text { i.v. amifostine. } 500 \\
\text { mg, versus RT }+ \\
\text { carboplatin } \\
\text { (control) }\end{array}$ & $\begin{array}{l}\text { i.v. amifostine treatment led to } \\
\text { significant reductions in acute } \\
\text { xerostomia, grade } \geq 3 \text { mucositis, and } \\
\text { grade } \geq 3 \text { thrombocytopenia compared } \\
\text { with control treatment }\end{array}$ \\
\hline Peters et al., 1999 & 28 & $\begin{array}{l}\text { RT + carboplatin }+ \\
\text { i.v. amifostine, } 500 \\
\text { mg, versus RT }+ \\
\text { carboplatin } \\
\text { (control) }\end{array}$ & $\begin{array}{l}\text { i.v. amifostine treatment had no } \\
\text { significant effect on xerostomia or } \\
\text { mucositis compared with control } \\
\text { treatment }\end{array}$ \\
\hline Atttonadou et al., 2002 & 50 & $\begin{array}{l}\mathrm{RT}+\text { carboplatin }+ \\
\text { i.v. amifostine, } 300 \\
\mathrm{mg} / \mathrm{m}^{2} \text {, versus } \mathrm{RT} \\
+ \text { carboplatin } \\
\text { (control) }\end{array}$ & $\begin{array}{l}\text { i.v. amifostine treatment led to } \\
\text { significant reduction in acute and late } \\
\text { grade } \geq 2 \text { xerostomia and grade } \geq 3 \\
\text { mucositis compared with control } \\
\text { treatment }\end{array}$ \\
\hline
\end{tabular}




\begin{tabular}{|c|c|c|c|}
\hline Study & $\begin{array}{l}\text { Number } \\
\text { of patients }\end{array}$ & Treatment & Main conclusions \\
\hline Vacha et al., 2003 & 52 & $\begin{array}{l}\text { RT + carboplatin }+ \\
\text { i.v. amifostine. } 250 \\
\text { mg, versus RT }+ \\
\text { carboplatin } \\
\text { (control) }\end{array}$ & $\begin{array}{l}\text { i.v. amifostine treatment led to } \\
\text { significant reduction in xerostomia } \\
\text { compared with control treatment: } \\
\text { reduction in mucositis was not } \\
\text { significant between treatment groups }\end{array}$ \\
\hline Bucntzel et al., 2006 & 132 & $\begin{array}{l}\text { RT + carboplatin + } \\
\text { i.v, amifostine, 200- } \\
300 \mathrm{mg} / \mathrm{m}^{2} \text {, versus } \\
\text { RT + carboplatin } \\
\text { (control) }\end{array}$ & $\begin{array}{l}\text { No difference between i.v, amifostine } \\
\text { treatment and control treatment with } \\
\text { regard to incidence of grade } \geq 2 \\
\text { xerostomia or grade } \geq 3 \text { mucositis: low } \\
\text { incidence of grade } \geq 2 \text { xerostomia and } \\
\text { grade } \geq 3 \text { mucositis in control patients; } \\
\text { no evidence of tumor protection was } \\
\text { Observed with either treatment }\end{array}$ \\
\hline
\end{tabular}

Table 1. Clinical trials of amifostine therapy during radiation therapy or radiochemotherapy for head and neck cancer

and neck in which at least $75 \%$ of each parotid gland was present in the radiation fields (Brizel et al., 2000). The amifostine dose was $200 \mathrm{mg} / \mathrm{m} 2$ daily, 15-30 minutes before each fraction of radiation therapy (1.8-2.0 Gy/day, 5 days per week for 5-7 weeks, to a total dose of 50-70 Gy). Amifostine significantly reduced acute and late xerostomia and associated symptoms. Using Radiation Therapy Oncology Group (RTOG) grading criteria, patients receiving amifostine had a lower incidence of grade 2 or higher acute xerostomia $(51 \%$ versus $78 \% ; \mathrm{p}<.001)$ and a lower incidence of grade 2 or higher late xerostomia ( $34 \%$ versus $57 \% ; p=.002)$. The proportion of patients with meaningful saliva production after 1 year was significantly higher with amifostine $(72 \%$ versus $49 \% ; p=.003)$. Despite a trend toward lower severity of mucositis with amifostine $(p=.14)$, the difference in the incidence of grade 3 or higher mucositis was not statistically significant $(p=.48)$. Importantly, at 1 year, with a median follow-up of 20 months, the locoregional tumor control rates did not differ, and disease-free and overall survival times were comparable. Two-year follow-up data from this study demonstrate the continued benefits of amifostine treatment on the incidence of grade 2 xerostomia $(p=.002$ versus patients who did not receive amifostine) (Wasserman et al., 2005). Furthermore, no significant differences in locoregional tumor control rate, progression-free survival time, or overall survival rates were observed 2 years post-treatment between the amifostine group and the control group (Wasserman et al., 2005).

In another study, 50 patients with head and neck cancer were randomized to receive radiotherapy plus carboplatin with or without amifostine (Antonadou et al., 2002). Treatment interruptions were more frequent in the control group. Consequently, patients receiving amifostine experienced significantly shorter treatment durations $(p=.013)$. Patients treated with amifostine experienced less severe acute mucositis and dysphagia; all patients who did not receive amifostine in the control group experienced grade 2 mucositis by week 3 . In contrast, only $9 \%$ of patients treated with amifostine experienced grade 2 mucositis $(\mathrm{p}<.001)$. By the fifth week, grade 4 mucositis was experienced by $52 \%$ and $4.5 \%$ 
of the patients in the respective groups $(\mathrm{p}<.001)$. Dysphagia was similarly reduced among patients given amifostine. After 3 months of follow-up, grade 2 xerostomia was reported in $27 \%$ and $74 \%$ of patients treated with and without amifostine, respectively $(\mathrm{p}<.001)$.

Another consideration in the treatment of head and neck cancer is the tolerance dose of the parotid glands and the potential for raising this threshold with amifostine. Eisbruch et al. [31] reported a threshold of $26 \mathrm{~Gy}$, using conformal or intensity-modulated radiotherapy, as a mean dose to spare parotid gland function (Eisbruch et al., 1999). With the use of amifostine, the threshold radiation dose for chronic xerostomia may be increased, allowing for greater dose coverage (Munter et al., 2007).

\subsection{Esophagitis and pneumonitis}

Damage from radiation treatment is also a major complication in the treatment of thoracic cancers, with higher rates of acute and late toxicity associated with concurrent chemoradiotherapy. Several studies have investigated the cytoprotective efficacy of amifostine against radiation-induced esophagitis and pneumonitis. Antonadou et al., in a multicenter trial of patients with advanced lung cancer, investigated whether daily pretreatment with amifostine could reduce the incidence of acute and late lung toxicity and esophagitis without affecting antitumor efficacy of radiation treatment (Antonadou et al., 2001). One hundred forty-six patients received radiotherapy in daily fractions of 2 Gy, 5 days per week, to a total of 55-60 Gy with or without daily amifostine, $340 \mathrm{mg} / \mathrm{m} 215$ minutes before irradiation. There was a significantly lower incidence of grade 2 or higher pneumonitis among patients receiving amifostine $(9 \%$ versus $43 \% ; p<.001)$. At 6 months post-treatment, fibrosis was present in $53 \%$ of patients not receiving amifostine compared with $28 \%$ of patients receiving amifostine $(\mathrm{p}<.05)$. The incidence of grade 2 or higher esophagitis during the fourth week of treatment was $4 \%$ among patients receiving amifostine, compared with $42 \%$ of patients receiving radiotherapy alone $(\mathrm{p}<.001)$. No evidence of tumor protection by amifostine was noted: complete or partial responses were observed in $75 \%$ and $76 \%$ of patients receiving amifostine or radiotherapy alone, respectively.

Komaki et al. evaluated the cytoprotective role of amifostine for esophagitis and hematologic and pulmonary toxicities in a randomized study of patients with stage II or III non-small cell lung cancer receiving concurrent chemoradiotherapy. Patients in the study group received amifostine, $500 \mathrm{mg}$ i.v., twice weekly before chemoradiation, and patients in the control group received chemoradiation without Amifostine (Komaki et al., 2004). The median survival time was longer, but not significantly so, for patients receiving amifostine (26 months versus 15 months). Significantly fewer patients who received amifostine also received morphine to relieve severe esophagitis $(7.4 \%)$ than patients who received chemoradiotherapy alone $(31 \% ; \mathrm{p}=.03)$. Amifostine treatment was also associated with a significantly lower incidence of acute pneumonitis $(3.7 \%$ versus $23 \%$; $=.037)$. Although not statistically significant, $26 \%$ of patients receiving amifostine had a complete response, compared with $8 \%$ of patients who did not receive amifostine $(p=.07)$.

Despite a limited number of studies, a recent meta-analysis reported that amifostine treatment was observed to reduce the incidence of pneumonitis and esophagitis for patients 
undergoing radiotherapy for lung cancer [6]. However, results from the largest multicenter study conducted to date were unable to show a reduction in the incidence of esophagitis with amifostine treatment (Movsas et al., 2005). A phase III study conducted by the RTOG (trial 9801) treated 243 patients with favorable-prognosis inoperable stage II-IIIA/B non-small cell lung cancer with concurrent hyperfractionated radiotherapy plus paclitaxel $(50 \mathrm{mg} / \mathrm{m} 2)$ and carboplatin (dosed to achieve area under the concentration-time curve of 2) (Movsas et al., 2005). Half of the patients also received i.v. amifostine $(500 \mathrm{mg})$ before the afternoon radiation treatment. During the course of the study, esophagitis was measured via National Cancer Institute Common Toxicity Criteria maximum esophagitis grade, physician dysphagia log, and patient daily self-assessment of swallowing ability. No significant differences in esophagitis were observed for patients receiving amifostine compared with those who did not receive amifostine, with the exception of the patient-reported lower rate of swallowing dysfunction observed in amifostine-treated patients $(\mathrm{z}$ test, $\mathrm{p}=.025)$. The authors attributed the lack of significant reduction in esophagitis with amifostine to several factors, including the timing of amifostine administration (Movsas et al., 2005), given that preclinical studies suggest that a single morning dose of amifostine provides superior radioprotection than with a single afternoon dose (Bachy et al., 2003; Fanzenbaker et al., 2003). The randomized trials involved in cytoprotection for lung irradiation are shown in table 2.

\subsection{Lower gastrointestinal mucositis}

Lower gastrointestinal mucositis frequently results from pelvic irradiation. Several clinical trials have demonstrated that amifostine pretreatment before radiotherapy or chemoradiotherapy can reduce the incidence and severity of gastrointestinal toxicities that commonly occur following these treatments (Table 2) (Koukourakis et al., 2000; Antonadou et al., 2004; Athanasiou et al., 2003; Ben-Josef et al., 2002; Dunst et al., 2000; Kouloulias et al., 2004; Kouloulias et al., 2005; Kouvaris et al., 2003; Liu et al., 1992; Simone et al., 2005; Singh et al., 2006). Guidelines published by the Mucositis Study Group of the Multinational Association of Supportive Care in Cancer/International Society for Oral Oncology recommend the use of amifostine $\left(340 \mathrm{mg} / \mathrm{m}^{2}\right)$ to prevent proctitis in patients receiving standard-dose radiotherapy (Bensadoun et al., 2006). Furthermore, these studies demonstrate that various routes of administration of amifostine (i.v., s.c., and intrarectal) are effective at reducing radiation- and chemoradiation-induced gastrointestinal toxicities in patients with pelvic malignancies. One study, conducted in 53 patients with prostate or gynecologic cancer, directly compared intrarectal amifostine administration with s.c. administration and found that intrarectal administration was more effective at reducing radiotherapy-induced rectal toxicities, whereas s.c. administration was more effective at reducing radiotherapy-induced urinary toxicities (Table 3) (Kouloulias et al., 2005). These results suggest that optimal cytoprotection may be achieved by combining routes of amifostine administration during treatment.

\subsection{Dermatitis}

Protection by amifostine against radiation-induced dermatitis was assessed in a retrospective analysis in which 100 patients with pelvic tumors treated with radiotherapy and amifostine were compared with 120 historical controls who was not administered 


\begin{tabular}{|c|c|c|c|c|}
\hline Reference & Radiation dose & Chemotherapy & Amifostine dose & Comment \\
\hline $\begin{array}{l}\text { Movsas et al., } \\
2005 \\
(n=242)\end{array}$ & $\begin{array}{l}69.6 \text { Gy at } 1.2 \mathrm{~Gy} \\
\text { (hyperfractionation) }\end{array}$ & Induction PC & $\begin{array}{l}500 \mathrm{mg} \text { i.v. } \\
4 \text { doses/wk } \\
\text { between RT } \\
\text { fractions }\end{array}$ & $\begin{array}{l}\text { No difference by NCI- } \\
\text { CTC esophagitis, } \\
\text { Swallowing diaries }(p< \\
0.03 \text { ) and weight loss }(p \\
<0.05 \text { ) favour amifostine } \\
\text { (median survival, } 15.6 \\
\text { and } 15.8 \mathrm{mo} \text { ) }\end{array}$ \\
\hline $\begin{array}{l}\text { Leong et al. , } \\
2003 \\
(n=60)\end{array}$ & $60-66 \mathrm{~Gy}$ at $2.0 \mathrm{~Gy}$ & Induction PC & $\begin{array}{l}740 \mathrm{mg} / \mathrm{m}^{2} \text { with } \\
\text { each chemo (Days } \\
1,22,43,50,57,64 \\
71,78)\end{array}$ & $\begin{array}{l}\text { Esophagitis Grade 2-3: } \\
43 \% \text { in amifostine, } 70 \% \\
\text { in control (not } \\
\text { significant) (median } \\
\text { survival, } 12.5 \text { and } 14.5 \\
\text { mo) }\end{array}$ \\
\hline $\begin{array}{l}\text { Senzer et al., } \\
2002 \\
(n=63)\end{array}$ & $64.8 \mathrm{~Gy}$ at $1.8 \mathrm{~Gy}$ & $\begin{array}{l}\text { Concurrent PC, } \\
\text { gemcitabine and } \\
\text { cisplatin X } 3 \text { after } \\
\text { chemoradiation }\end{array}$ & $\begin{array}{l}500 \mathrm{mg} \text { i.v. before } \\
\text { weekly chemo; } 200 \\
\text { mg i.v. daily } \\
\text { before RT }\end{array}$ & $\begin{array}{l}\text { No difference in toxicity, } \\
\text { no survival data } \\
\text { (ongoing trial) }\end{array}$ \\
\hline $\begin{array}{l}\text { Antonadou et } \\
\text { al., } 2001 \\
(n=146)\end{array}$ & $55-60 \mathrm{~Gy}$ at $2.0 \mathrm{~Gy}$. & None & $\begin{array}{l}340 \mathrm{mg} / \mathrm{m}^{2} / \mathrm{d} \\
\text { before RT }\end{array}$ & $\begin{array}{l}\downarrow \text { Pneumonitis } \\
\downarrow \text { Esophagitis (no } \\
\text { survival data) }\end{array}$ \\
\hline $\begin{array}{l}\text { Antonadou et } \\
\text { al., } 2003 \\
(n=73)\end{array}$ & $55-60 \mathrm{~Gy}$ at $2.0 \mathrm{~Gy}$. & $\begin{array}{l}\text { Concurrent } \\
\text { weekly Por C }\end{array}$ & $\begin{array}{l}300 \mathrm{mg} / \mathrm{m}^{2} / \mathrm{d} \\
\text { before } \\
\text { chemoradiation } \\
\text { and RT }\end{array}$ & $\begin{array}{l}\lfloor\text { esophagitis }(p<0.001) \\
\downarrow \text { pneumonitis }(p=0.009) \\
\text { (no survival data) }\end{array}$ \\
\hline $\begin{array}{l}\text { Komaki et al., } \\
2004 \\
(n=62)\end{array}$ & $\begin{array}{l}69.6 \text { Gy at } 1.2 \mathrm{~Gy} \\
\text { (hyperfractionation) }\end{array}$ & $\begin{array}{l}\text { Concurrent i.v. } \\
\text { cisplatin Days 1, } \\
\text { 8,29, 36; Oral } \\
\text { etoposide Days1-5 } \\
\text { 8-12, 29-33,36-40 }\end{array}$ & $\begin{array}{l}500 \mathrm{mg} \text { i.v. 1st, 2nd } \\
\text { day each wk } \\
\text { before chemo and } \\
\text { 1st RT fraction }\end{array}$ & $\begin{array}{l}\downarrow \text { Degree of esophagitis, } \\
\downarrow \text { Pneumonitis, } \\
\downarrow \text { Neutropenic fever } \\
\text { (median survival,19 and } \\
20 \text { mo) }\end{array}$ \\
\hline
\end{tabular}

Abbreviations: $\mathrm{P}=$ paclitaxel $; \mathrm{C}=$ carboplatin; $\mathrm{RT}=$ radiotherapy; $\mathrm{NCI}-\mathrm{CTC}=$ National Cancer InstituteCommon Toxicity Criteria.

Table 2. Randomized trials with amifostine in lung cancer

amifostine (Kouvaris et al., 2002). There was a 77\% lower risk for radiation-induced dermatitis with amifostine use. The severity of dermatitis was also significantly lower among patients receiving amifostine compared with historical controls: the mean gross dermatitis scores were $0.18 \pm 0.09$ versus $1.0 \pm 0.11(p<.001)$. In another study of 40 patients receiving radiation treatment for pelvic tumors, grade 2 or 3 dermatitis of the perineal/vulvar area was observed in all patients with gynecologic and rectal cancer who did not receive amifostine (500 mg s.c.) (Koukourakis et al., 20000). Among patients who received amifostine, only grade 1 dermatitis was noted. 


\begin{tabular}{|c|c|c|c|c|}
\hline Author & $\mathbf{N}$ & $\begin{array}{l}\text { Rectal Toxicity (Control vs } \\
\text { Amifostine) }\end{array}$ & $\begin{array}{l}\mathbf{P} \\
\text { Value }\end{array}$ & Remarks \\
\hline Liu et al., 1992 & 100 & $\begin{array}{l}14 \% \text { vs } 0 \% ; \text { moderate or } \\
\text { severe late toxicities }\end{array}$ & 0.03 & Randomized (intravenous) \\
\hline $\begin{array}{l}\text { Dunst et al., } \\
2000\end{array}$ & 30 & $\begin{array}{l}1.07 \pm 1.03 \text { vs } 0.40 \pm 0.63 \\
\text { maximum diarrhea score }\end{array}$ & 0.044 & $\begin{array}{l}\text { Nonrandomized } \\
\text { (intravenous) }\end{array}$ \\
\hline $\begin{array}{l}\text { Antonadou et } \\
\text { al., } 2004\end{array}$ & 124 & $\begin{array}{l}5.6 \% \text { for amifostine vs } 22.2 \% \\
\text { for control }\end{array}$ & $<0.011$ & Randomized \\
\hline $\begin{array}{l}\text { Kligerman et al., } \\
1992\end{array}$ & 100 & $\begin{array}{l}5 \% \text { vs } 0 \% \text { moderate or severe } \\
\text { late toxicity }\end{array}$ & $<0.01$ & Randomized (intravenous) \\
\hline $\begin{array}{l}\text { Kouvaris et al., } \\
2002\end{array}$ & 220 & $\begin{array}{l}\text { Grade I/II toxicity, } 70 \% \text { vs } \\
42 \%\end{array}$ & $<0.001$ & $\begin{array}{l}\text { Nonrandomized } \\
\text { (retrospective, intravenous) }\end{array}$ \\
\hline $\begin{array}{l}\text { Ben-Josef et al., } \\
2002\end{array}$ & 29 & $\begin{array}{l}\text { Grade I/II toxicity, } 50 \% \\
(500-1000 \mathrm{mg} \text { amifostine) vs } \\
15 \%(1500-2500 \mathrm{mg} \\
\text { amifostine) }\end{array}$ & 0.0325 & $\begin{array}{l}\text { Nonrandomized } \\
\text { (intrarectal) }\end{array}$ \\
\hline $\begin{array}{l}\text { Koukourakis et } \\
\text { al., } 2000\end{array}$ & 40 & $\begin{array}{l}\text { Grade III/IV observed in } \\
15 \% \text { for control vs } 0 \% \text { for } \\
\text { amifosine group }\end{array}$ & $<0.05$ & Randomized \\
\hline $\begin{array}{l}\text { Kouvaris et al., } \\
2003\end{array}$ & 36 & $\begin{array}{l}\text { Grade I/II toxicity, } 88 \% \text { vs } \\
11 \%\end{array}$ & $<0.001$ & Randomized (intravenous) \\
\hline $\begin{array}{l}\text { Muller et al., } \\
2004\end{array}$ & 6 & $\begin{array}{l}\text { Leukocytes and lymphocytes } \\
\text { irradiated were } \\
\text { radioprotected (comet assay } \\
\text { measurements) }\end{array}$ & $<0.05$ & Nonrandomized \\
\hline $\begin{array}{l}\text { Athanasiou et } \\
\text { al., } 2003\end{array}$ & 205 & $\begin{array}{l}\text { Grade II/III acute toxicity, } \\
22.1 \% \text { vs } 5.5 \% \text { (3rd wk of } \\
\text { radiation) }\end{array}$ & 0.001 & Randomized (intravenous) \\
\hline $\begin{array}{l}\text { Kouloulias et } \\
\text { al., } 2004\end{array}$ & 67 & $\begin{array}{l}\text { Grade I/II acute toxicity, } \\
44 \% \text { vs } 15 \% \text { for IR }\end{array}$ & 0.026 & Randomized (intrarectal) \\
\hline $\begin{array}{l}\text { Singh et al., } \\
\text { 2006; Simone et } \\
\text { al., } 2005\end{array}$ & 30 & $33 \%$ in $1 \mathrm{gr}$ IR vs $0 \%$ in $2 \mathrm{gr}$ IR & 0.06 & Randomized \\
\hline $\begin{array}{l}\text { Kouloulias et } \\
\text { al., } 2005\end{array}$ & 53 & $\begin{array}{l}\text { Grade I/II acute toxicity, } \\
42 \% \text { for s.c. Vs } 11 \% \text { for IR }\end{array}$ & 0.04 & $\begin{array}{l}\text { Randomized (subcutaneous } \\
\text { vs intrarectal) }\end{array}$ \\
\hline
\end{tabular}

$\mathrm{IR}=$ intrarectal; s.c. $=$ subcutneous

Table 3. Clinical Trials of Amifostine With Radiotherapy in Pelvic Tumors

\section{Different ways of administration}

\section{1 i.v. Amifostine}

The American Society of Clinical Oncology guidelines for cytoprotective agents recommend amifostine at a dose of $200 \mathrm{mg} / \mathrm{m}^{2}$ daily, given as a slow i.v. push over 3 minutes, 15-30 minutes before each fraction of radiation therapy (Hensley et al., 1999). Adverse events are reduced at this lower dose. Nonetheless, administration of amifostine requires close patient monitoring. Many patients require antiemetics. Hypotension associated with amifostine at this dose is less frequent but still requires close monitoring. Blood pressure should be measured before and immediately after the 3-minute amifostine infusion. 


\section{2 s.c. Amifostine}

The s.c. administration of amifostine has been proposed to reduce treatment-related and dose-limiting adverse events (Koukourakis et al., 20000). In a pharmacokinetic study, the plasma concentration of WR-1605 after s.c. injection of $500 \mathrm{mg}$ of amifostine was $67 \%$ of that after a $200 \mathrm{mg} / \mathrm{m} 2$ i.v. dose (Shaw et al., 1997). Lower plasma levels of amifostine after s.c. injection do not necessarily translate to lower tissue concentrations. Because the amount of amifostine that is absorbed and converted to the active metabolites is not dependent on plasma pharmacokinetics, i.v. or s.c. administration may not have a significant impact on whether therapeutic levels are achieved in the tissues. Precise determination of the protective efficacy of different routes of administration will require more comprehensive studies that measure intracellular levels of the metabolites or assess radiation-induced DNA double-strand breaks in tissues after i.v. or s.c. administration of amifostine. Nonetheless, the efficacy of s.c. amifostine administration is best addressed in the context of a clinical trial.

A phase II randomized trial with 140 patients assessed the feasibility, tolerance, and activity of the s.c. route (Koukourakis et al., 20000). A dose of amifostine of $500 \mathrm{mg}$ s.c. was administered 20 minutes before each fraction of radiotherapy. The s.c. administration of amifostine was well tolerated by $85 \%$ of patients. In approximately $15 \%$ of patients, amifostine therapy was interrupted because of cumulative asthenia or a fever/rash reaction. Mild nausea was frequent $(29 \%)$, and the incidence of hypotension was negligible $(3 \%)$. Significantly less pharyngeal, esophageal, and rectal mucositis was observed among patients receiving amifostine $(p<.04)$. Treatment delays because of grade 3 mucositis were significantly longer in patients treated with radiotherapy alone $(p<.04)$.

\subsection{Endorectal}

Initial attempts with rectal administration of amifostine admixed in a foam did not demonstrate protection in patients receiving large pelvic fields of radiation (Montana et al., 1992). However, after successful topical application of amifostine in the rectum of male rats (Ben-Josef et al., 1995), subsequent significant clinical benefit of endorectal administration of amifostine was demonstrated in a phase I study (Ben-Josef et al., 2002).

A randomized trial of 67 patients undergoing radiotherapy for prostate cancer further assessed intrarectal administration of amifostine (Kouloulias et al., 2002). Patients were treated with or without amifostine at a dose of 1,500 mg intrarectally 20-30 minutes before each radiotherapy session. All patients receiving amifostine completed therapy without amifostine-related toxicities, suggesting that intrarectal amifostine was feasible and well tolerated. According to RTOG grading criteria, amifostine was superior to no treatment, with a significantly lower incidence of rectal mucositis $(15 \%$ versus $44 \% ; p<.04)$. The mean rectal mucositis index of patients who received amifostine was $0.3 \pm 0.1$ compared with $2.2 \pm$ 0.4 in patients without cytoprotection $(p<.001)$. The severity of rectal mucositis was significantly lower in patients who received amifostine $(p<.001)$. Urinary toxicity was comparable between the two groups $(p=.76)$. A more recent study suggests that the efficacy of intrarectal amifostine may be dose dependent. Although not statistically significant, the incidence of acute grade 2 rectal mucositis was lower in patients receiving a 2-g suspension of amifostine $(n=12)$ than in those receiving $1 \mathrm{~g}(n=18 ; p=.06)$ (Sigh et al., 2006). No breaks 
in treatment for radiation-induced toxicities were required in that study. A combination of intrarectal and s.c. amifostine administration might be optimal for cytoprotection with pelvic irradiation.

\section{New grading scale for acute pelvic radiation induced toxicity}

The past years all the trials with amifostine and pelvic radiotherapy used as endpoints the WHO and RTOG/EORTC scales as shown in table 4.

\begin{tabular}{|c|c|c|c|c|c|}
\hline & $\begin{array}{l}\text { Grade } \\
0\end{array}$ & Grade 1 & Grade 2 & Grade 3 & Grade 4 \\
\hline $\begin{array}{l}\text { WHO } \\
\text { Toxicity } \\
\text { Grade }\end{array}$ & None & $\begin{array}{l}\text { Increase of 2-3 } \\
\text { stools per d } \\
\text { over } \\
\text { pretreatment }\end{array}$ & $\begin{array}{l}\text { Increase of } 4-6 \\
\text { stools per d, or } \\
\text { nocturnal stools, or } \\
\text { moderate cramping }\end{array}$ & $\begin{array}{l}\text { Increase of 7-9 } \\
\text { stools per d, or } \\
\text { incontinence, } \\
\text { or severe } \\
\text { cramping }\end{array}$ & $\begin{array}{l}\text { Increase of }>10 \text { stools } \\
\text { per d or grossly } \\
\text { bloody diarrhea, or } \\
\text { need for parenteral } \\
\text { support }\end{array}$ \\
\hline $\begin{array}{l}\text { EORTC- } \\
\text { RTOG scale } \\
\text { for lower } \\
\text { gastro- } \\
\text { intestinal }\end{array}$ & None & $\begin{array}{l}\text { Increased } \\
\text { frequency or } \\
\text { change in } \\
\text { quality of } \\
\text { bowel habits } \\
\text { not requiring } \\
\text { medication, } \\
\text { rectal } \\
\text { discomfort not } \\
\text { requiring } \\
\text { analgesics }\end{array}$ & $\begin{array}{l}\text { Diarrhea requiring } \\
\text { parasympatholytic } \\
\text { drugs, mucous } \\
\text { discharge not } \\
\text { necessitating } \\
\text { sanitary pads, rectal } \\
\text { or abdominal pain } \\
\text { requiring analgesics }\end{array}$ & $\begin{array}{l}\text { Diarrhea } \\
\text { requiring } \\
\text { parenteral } \\
\text { support, severe } \\
\text { mucous or } \\
\text { blood } \\
\text { discharge } \\
\text { necessitating } \\
\text { sanitary } \\
\text { pads/abdomin } \\
\text { al distension } \\
\text { (flat plate } \\
\text { radiograph } \\
\text { demonstrates } \\
\text { distended } \\
\text { bowel loops) }\end{array}$ & $\begin{array}{l}\text { Acute or subacute } \\
\text { obstruction, fistula or } \\
\text { perforation; } \\
\text { gastrointestinal } \\
\text { bleeding requiring } \\
\text { transfusion; } \\
\text { abdominal pain or } \\
\text { tenesmus requiring } \\
\text { tube decompression } \\
\text { or bowel diversion }\end{array}$ \\
\hline
\end{tabular}

EORTC-RTOG= European Organization for Research and Treatment of Cancer/Radiation Therapy Oncology Group; WHO=World Health Organization.

Table 4. WHO Toxicity Criteria and RTOG Acute Radiation Morbidity Scoring Criteria

A specific analytical for subjective and objective measurements was introduced. Endoscopy offers accurate endpoints for the evaluation of tissue damage, whereas the criteria of rectosigmoidoscopy findings are still not well defined in the literature. The literature deals mainly with symptomatic patients presenting with rectal bleeding, pain, increased stool frequency, urgency and incontinence, whereas systematic endoscopic analysis including asymptomatic patients rarely exists. A valid scoring system is essential for adequate description of acute rectal toxicity. For the benefit of sharing and comparing data collected from endoscopy after RT, we have introduced a graduation system based on 
rectosigmoidoscopic criteria focused on acute effects and standardized terminology published by the European Society for Gastrointestinal Endoscopy. The scale is shown in table 5 .

\begin{tabular}{|c|c|c|c|c|}
\hline & Grade 1 & Grade 2 & Grade 3 & Grade 4 \\
\hline \multicolumn{5}{|l|}{ Subjective } \\
\hline Tenesmus & Occasional urgency & $\begin{array}{l}\text { Intermittent } \\
\text { urgency }\end{array}$ & $\begin{array}{l}\text { Persistent } \\
\text { urgency }\end{array}$ & Refractory \\
\hline Mucosal loss & Occasional & Intermittent & Persistent & Refractory \\
\hline $\begin{array}{l}\text { Sphincter } \\
\text { control }\end{array}$ & Occasional & Intermittent & Persistent & Refractory \\
\hline Stool frequency & $2-4$ per $d$ & $4-8$ per $d$ & $>8$ per $d$ & $\begin{array}{l}\text { Uncontrolled } \\
\text { diarrhoea }\end{array}$ \\
\hline Pain & $\begin{array}{l}\text { Occasional \& } \\
\text { minimal }\end{array}$ & $\begin{array}{l}\text { Intermittent \& } \\
\text { tolerable }\end{array}$ & $\begin{array}{l}\text { Persistent \& } \\
\text { intense }\end{array}$ & $\begin{array}{l}\text { Refractory \& } \\
\text { excruciating }\end{array}$ \\
\hline \multicolumn{5}{|l|}{ Objective } \\
\hline Bleeding & Occult & $\begin{array}{l}\text { Occasionally }>2 \\
\text { per wk }\end{array}$ & Persistent, daily & $\begin{array}{l}\text { Gross } \\
\text { hemorrhage }\end{array}$ \\
\hline Mucosa surface & $\begin{array}{l}\text { Localized spotted, } \\
\text { congested mucosa }\end{array}$ & $\begin{array}{l}\text { Punctate, } \\
\text { congested } \\
\text { mucosa }\end{array}$ & $\begin{array}{l}\text { Diffused, } \\
\text { congested } \\
\text { mucosa }\end{array}$ & Bleeding mucosa \\
\hline Ulceration & Superficial $\leq 1 \mathrm{~cm}^{2}$ & $\begin{array}{l}\text { Superficial >1 } \\
\mathrm{cm}^{2}\end{array}$ & Deep ulcer & $\begin{array}{l}\text { Surgical } \\
\text { intervention }\end{array}$ \\
\hline
\end{tabular}

*Modification to Subjective Objective Management Analytic scale to fit radiation-induced acute toxicity to the rectum. Subjective and objective items were used for evaluation of acute radiation-induced rectal mucositis. The second and third items of the objective scale were based on findings from flexible rectosigmoidoscopy and were in accordance with the endoscopic terminology of the World Organization for Digestive Endoscopy. The final score was the sum of scores of the 8 items (score $=0$ in the absence of toxicity).

\section{Table 5. Rectal Toxicity Grade*}

Our experience has shown that the terminology is practicable and provides a definition of terms usable by radiation oncologist and endoscopists. The S-RS scale showed a satisfied clinical validity and reliability (Kouvaris etal., 2003). In a previous publication (Kouloulias et al., 2004) the rectosigmoidoscopic findings for amifostine versus no amifostine showed significant differences, as shown in figure 1.

\section{Conclusion}

Normal tissues vary in the extent that they are protected from radiation damage by amifostine. Because amifostine does not cross the blood-brain barrier, the central nervous system, often the dose-limiting organ in radiotherapy, is not protected (Millar et al., 1982; Washburn et al., 1976). Protection factors for other tissues range from three in the hematopoietic system and salivary glands to approximately one in the lung, kidney, and bladder (Rojas et al., 1984; Rojas et al., 1986; Travis 1984). Within the same tissues, a range of protection factors has been reported (Rojas et al., 1984; Mori et al., 1984). Discrepancies in WR-1065 concentrations in tissues within 15-30 minutes of administration (Utley et al., 1984) 
and the normal interval between administration of amifostine and radiotherapy may explain these differences. Nonhomogenous distribution of amifostine and its metabolites within a tissue, even at the level of the DNA (savoye et al., 1997), may also contribute to this heterogeneity.

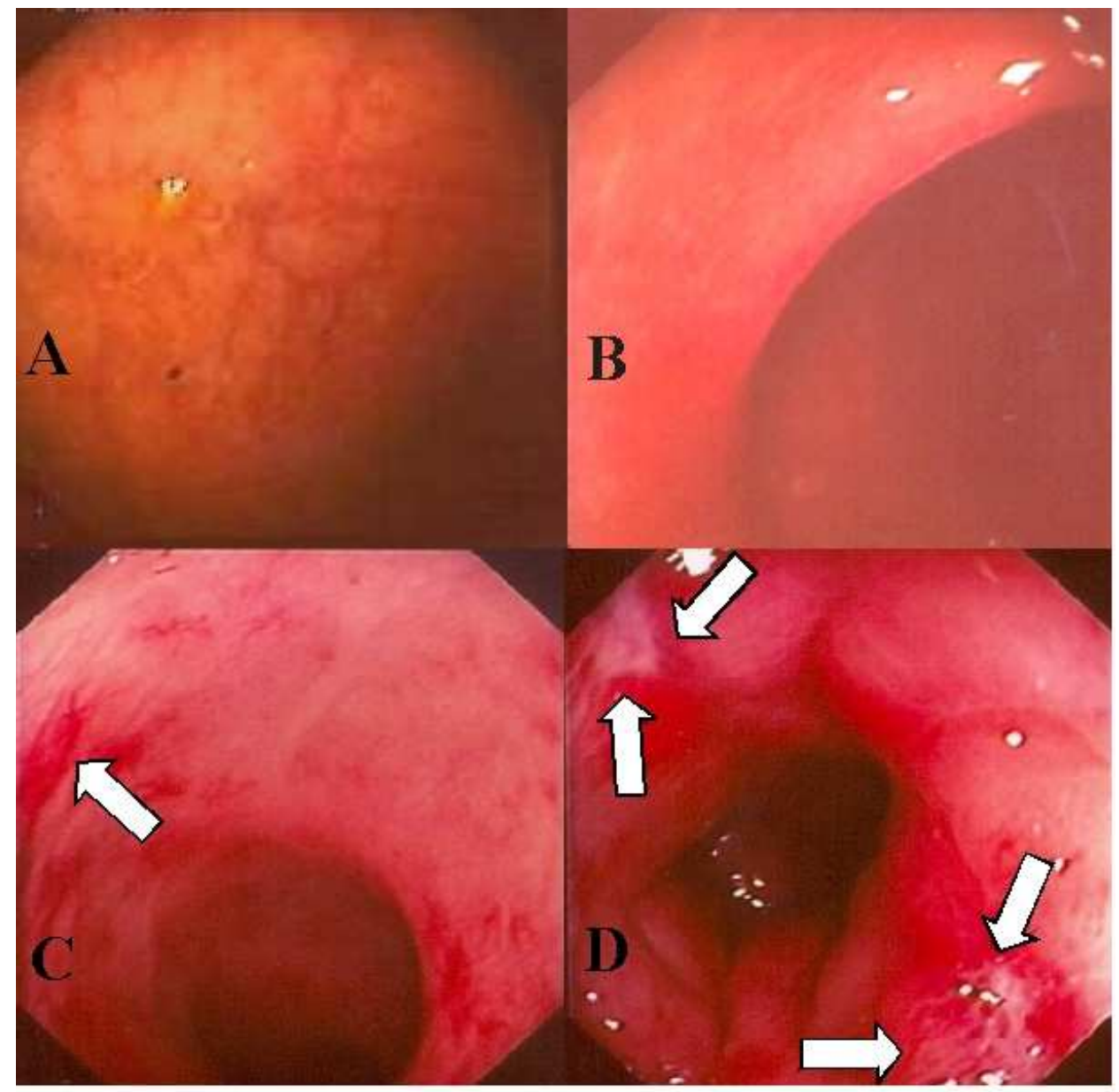

Fig. 1. Rectosigmoidoscopic findings. Panels A and B illustrate a regular rectal mucosa in patients after intrarectal administration of amifostine. Panels $C$ and $D$ are from patients who did not receive amifostine and illustrate congested mucosa with superficial ulceration $>1$ $\mathrm{cm}^{2}$ (indicated by the arrows).

The U.S. Food and Drug Administration has approved the i.v. use of amifostine to reduce the cumulative renal toxicity associated with repeated administration of cisplatin in patients with advanced ovarian cancer and to reduce the incidence of moderate to severe xerostomia in patients undergoing postoperative radiation treatment for head and neck cancer, where the radiation port includes a substantial portion of the parotid glands. Amifostine has been 
proven to be a useful addition to the arsenal of the radiation oncologist, helping improve patients' quality of life and in some cases allowing more aggressive radio- and chemotherapeutic regimens. Currently, s.c. administration of amifostine is a standard practice for patients with head and neck cancer as well as for patients with recurrent ovarian carcinoma (Hensley et al., 2009), while there is evidence now that the s.c is not superior to i.v. administration of amifostine (Bardet et al., 2011). Refinements in doses and administration of amifostine lead to constant improvement in the adverse event profile, resulting in fewer interruptions in treatment and ultimately improving patient outcomes (Jellena et al., 2006; Bourhis et al., 2011). At last but not least, recent meta-analysis from 16 randomized trials (1,554 patients) confirmed the lack of any tumor protection in routine radiotherapy practice when amifostine is administered (Bourhis et al., 2011).

It has to be mentioned that the graduation system designed by our group is user-friendly and more than this, it is an interface between radiation-oncologists and gastroenterologists by means of common terminology between specializations for radiation induced rectal toxicity.

\section{References}

American Cancer Society. Cancer Facts and Figures 2005. Atlanta, GA: American Cancer Society, 2005:60.

Anne PR, Curran WJ Jr. A phase II trial of subcutaneous amifostine and radiation therapy in patients with head and neck cancer. Semin Radiat Oncol 2002;12(suppl 1):18-19.

Anne PR, Machtay M, Rosenthal DI et al. A Phase II trial of subcutaneous amifostine and radiation therapy in patients with head-and-neck cancer. Int J Radiat Oncol Biol Phys 2007;67:445-452.

Antonadou D, Athanassiou H, Sarris N et al. Final results of a randomized phase III trial of chemoradiation treatment + amifostine in patients with colorectal cancer: Clinical Radiation Oncology Hellenic Group. Presented at the 46th Annual Meeting of the American Society for Therapeutic Radiology and Oncology; October 3-7; Atlanta, GA, 2004.

Antonadou D, Coliarakis N, Synodinou M et al. Randomized phase III trial of radiation treatment +/- amifostine in patients with advanced-stage lung cancer. Int J Radiat Oncol Biol Phys 2001;51:915-922.

Antonadou D, Pepelassi M, Synodinou M et al. Prophylactic use of amifostine to prevent radiochemotherapy-induced mucositis and xerostomia in head-and-neck cancer. Int J Radiat Oncol Biol Phys 2002;52:739-747.

Antonadou D, Throuvalas N, Petridis A, et al. Effect of amifostine on toxicities associated with radiochemotherapy in patients with locally advanced non-small-cell lung cancer. Int J Radiat Oncol Biol Phys 2003;57:402-408.

Athanassiou H, Antonadou D, Coliarakis N et al. Protective effect of amifostine during fractionated radiotherapy in patients with pelvic carcinomas: Results of a randomized trial. Int J Radiat Oncol Biol Phys 2003;56:1154-1160.

Bachy CM, Fazenbaker CA, Kifle G et al. Daily dosing with amifostine is necessary for full protection against oral mucositis caused by fractionated radiation in rats: Protection and pharmacokinetics. Proc Am Soc Clin Oncol 2003;22:518. 
Bardet E, Martin L, Calais G, et al. Subcutaneous compared with intravenous administration of amifostine in patients with head and neck cancer receiving radiotherapy: final results of the GORTEC2000-02 phase III randomized trial.J Clin Oncol. 2011 Jan 10;29(2):127-33.

Ben-Josef E, Han S, Tobi M et al. A pilot study of topical intrarectal application of amifostine for prevention of late radiation rectal injury. Int J Radiat Oncol Biol Phys 2002;53:1160-1164.

Ben-Josef E, Mesina J, Shaw LM et al. Topical application of WR-2721 achieves high concentrations in the rectal wall. Radiat Res 1995;143:107-110.

Bensadoun RJ, Schubert MM, Lalla RV et al. Amifostine in the management of radiationinduced and chemo-induced mucositis. Support Care Cancer 2006;14:566-572.

Blumberg AL, Nelson DF, Gramkowski M et al. Clinical trials of WR-2721 with radiation therapy. Int J Radiat Oncol Biol Phys 1982;8:561-563.

Bourhis J, Blanchard P, Maillard E, et al. Effect of Amifostine on Survival Among Patients Treated With Radiotherapy: A Meta-Analysis of Individual Patient Data. J Clin Oncol. 2011 May 16.

Bourhis J, De Crevoisier R, Abdulkarim B et al. A randomized study of very accelerated radiotherapy with and without amifostine in head and neck squamous cell carcinoma. Int J Radiat Oncol Biol Phys 2000;46:1105-1108.

Brizel DM, Wasserman TH, Henke M et al. Phase III randomized trial of amifostine as a radioprotector in head and neck cancer. J Clin Oncol 2000;18:3339-3345.

Buentzel J, Micke O, Adamietz IA et al. Intravenous amifostine during chemoradiotherapy for head-and-neck cancer: A randomized placebo-controlled phase III study. Int J Radiat Oncol Biol Phys 2006;64:684-691.

Buntzel J, Glatzel M, Frohlich D et al. Intensification of radiochemotherapy with Ethyol in head and neck cancer. Proc Am Soc Clin Oncol 1998;17:403A.

Buntzel J, Kuttner K, Frohlich D et al. Selective cytoprotection with amifostine in concurrent radiochemotherapy for head and neck cancer. Ann Oncol 1998;9:505-509.

Calabro-Jones PM, Fahey RC, Smoluk GD et al. Alkaline phosphatase promotes radioprotection and accumulation of WR-1065 in V79-171 cells incubated in medium containing WR-2721. Int J Radiat Biol Relat Stud Phys Chem Med 1985;47:23-27.

Carmeliet P, Dor Y, Herbert JM et al. Role of HIF-1alpha in hypoxia-mediated apoptosis, cell proliferation and tumour angiogenesis. Nature 1998;394:485-490.

Dunst J, Semlin S, Pigorsch S et al. Intermittent use of amifostine during postoperative radiochemotherapy and acute toxicity in rectal cancer patients. Strahlenther Onkol 2000;176:416-421.

Eisbruch A, Ten Haken RK, Kim HM et al. Dose, volume, and function relationships in parotid salivary glands following conformal and intensity-modulated irradiation of head and neck cancer. Int J Radiat Oncol Biol Phys 1999;45:577-587.

Fazenbaker CA, Bachy CM, Kifle G et al. Dose and schedule dependency of amifostine protection against hyperfractionated radiotherapy in a rat model. Proc Am Soc Clin Oncol 2003;22:518.

Glover D, Negendank W, Delivoria-Papadopoulos M et al. Alterations in oxygen transport following WR-2721. Int J Radiat Oncol Biol Phys 1984;10:1565-1568. 
Glover D, Riley L, Carmichael K et al. Hypocalcemia and inhibition of parathyroid hormone secretion after administration of WR-2721 (a radioprotective and chemoprotective agent). N Engl J Med 1983;309:1137-1141.

Hensley ML, Hagerty KL, Kewalramani T, et al. American Society of Clinical Oncology 2008 clinical practice guideline update: use of chemotherapy and radiation therapy protectants. J Clin Oncol. 2009 Jan 1;27(1):127-45.

Hensley ML, Schuchter LM, Lindley C et al. American Society of Clinical Oncology clinical practice guidelines for the use of chemotherapy and radiotherapy protectants. J Clin Oncol 1999;17:3333-3355.

Jellema AP, Slotman BJ, Muller MJ, et al. Radiotherapy alone, versus radiotherapy with amifostine 3 times weekly, versus radiotherapy with amifostine 5 times weekly: A prospective randomized study in squamous cell head and neck cancer. Cancer. 2006 Aug 1;107(3):544-53.

Kajstura J, Cheng W, Reiss K et al. Apoptotic and necrotic myocyte cell deaths are independent contributing variables of infarct size in rats. Lab Invest 1996;74:86-107.

Kligerman MM, Liu T, Liu Y, Scheffler B, He S, Zhang Z. Interim analysis of a randomized trial of radiation therapy of rectal cancer with/without WR-2721. Int J Radiat Oncol Biol Phys. 1992;22(4):799-802

Komaki R, Lee JS, Milas L, et al. Effects of amifostine on acute toxicity from concurrent chemotherapy and radiotherapy for inoperable non-small-cell lung cancer: report of a randomized comparative trial. Int J Radiat Oncol Biol Phys. 2004;58(5):1369-77

Koukourakis MI, Flordellis CS, Giatromanolaki A et al. Oral administration of recombinant human granulocyte macrophage colony-stimulating factor in the management of radiotherapy-induced esophagitis. Clin Cancer Res 1999;5:3970-3976.

Koukourakis MI, Kyrias G, Kakolyris S et al. Subcutaneous administration of amifostine during fractionated radiotherapy: A randomized phase II study. J Clin Oncol 2000;18:2226-2233.

Koukourakis MI. Amifostine: Is there evidence of tumor protection? Semin Oncol 2003;30(suppl 18):18-30.

Kouloulias VE, Kouvaris JR, Pissakas G et al. A phase II randomized study of topical intrarectal administration of amifostine for the prevention of acute radiationinduced rectal toxicity. Strahlenther Onkol 2004;180:557-562.

Kouloulias VE, Kouvaris JR, Pissakas G et al. Phase II multicenter randomized study of amifostine for prevention of acute radiation rectal toxicity: Topical intrarectal versus subcutaneous application. Int J Radiat Oncol Biol Phys 2005;62:486-493.

Kouvaris J, Kouloulias V, Kokakis J et al. The cytoprotective effect of amifostine in acute radiation dermatitis: A retrospective analysis. Eur J Dermatol 2002;12:458-462.

Kouvaris J, Kouloulias V, Kokakis J, Matsopoulos G, Balafouta M, Miliadou A, Vlahos L. Cytoprotective effect of amifostine in radiation-induced acute mucositis - a retrospective analysis. Onkologie. 2002 Aug;25(4):364-9.

Kouvaris J, Kouloulias V, Malas E et al. Amifostine as radioprotective agent for the rectal mucosa during irradiation of pelvic tumors. A phase II randomized study using various toxicity scales and rectosigmoidoscopy. Strahlenther Onkol 2003;179:167-174.

Leong SS, Tan EH, Fong K, et al. Randomized double-blind trial of combined modality treatment with or without amifostine in unresectable stage III non-small-cell lung cancer. J Clin Oncol 2003;21:1767-1774. 
Liu T, Liu Y, He S et al. Use of radiation with or without WR-2721 in advanced rectal cancer. Cancer 1992;69:2820-2825.

McDonald S, Meyerowitz C, Smudzin T et al. Preliminary results of a pilot study using WR2721 before fractionated irradiation of the head and neck to reduce salivary gland dysfunction. Int J Radiat Oncol Biol Phys 1994;29:747-754.

Millar JL, McElwain TJ, Clutterbuck RD et al. The modification of melphalan toxicity in tumor bearing mice by s-2-(3-aminopropylamino)- ethylphosphorothioic acid (WR 2721). Am J Clin Oncol 1982;5:321-328.

Montana GS, Anscher MS, Mansbach CM 2nd et al. Topical application of WR-2721 to prevent radiation-induced proctosigmoiditis. A phase I/II trial. Cancer 1992;69:2826-2830.

Mori T, Nikaido O, Sugahara T. Dephosphorylation of WR-2721 with mouse tissue homogenates. Int J Radiat Oncol Biol Phys 1984;10:1529-1531.

Movsas B, Scott C, Langer C et al. Randomized trial of amifostine in locally advanced nonsmall-cell lung cancer patients receiving chemotherapy and hyperfractionated radiation: Radiation Therapy Oncology Group trial 98-01. J Clin Oncol 2005;23:2145-2154.

Müller AC, Pigorsch S, Beyer C, et al. Radioprotective effects of amifostine in vitro and in vivo measured with the comet assay. Strahlenther Onkol. 2004 Aug;180(8):517-25.

Munter MW, Hoffner S, Hof $\mathrm{H}$ et al. Changes in salivary gland function after radiotherapy of head and neck tumors measured by quantitative pertechnetate scintigraphy: Comparison of intensity-modulated radiotherapy and conventional radiation therapy with and without amifostine. Int J Radiat Oncol Biol Phys 2007;67:651-659.

Peters K, Mucke R, Hamann D et al. Supportive use of amifostine in patients with head and neck tumors undergoing radio-chemotherapy. Is it possible to limit the duration of the application of amifostine? Strahlenther Onkol 1999;175(suppl 4):23-26.

Purdie JW, Inhaber ER, Schneider H et al. Interaction of cultured mammalian cells with WR2721 and its thiol, WR-1065: Implications for mechanisms of radioprotection. Int J Radiat Biol Relat Stud Phys Chem Med 1983;43:517-527.

Rojas A, Denekamp J. The influence of $\mathrm{X}$ ray dose levels on normal tissue radioprotection by WR-2721. Int J Radiat Oncol Biol Phys 1984;10:2351-2356.

Rojas A, Stewart FA, Soranson JA et al. Fractionation studies with WR-2721: Normal tissues and tumour. Radiother Oncol 1986;6:51-60.

Rubin DB, Drab EA, Kang HJ et al. WR-1065 and radioprotection of vascular endothelial cells. I. Cell proliferation, DNA synthesis and damage Radiat Res, 1996;145:210-216.

Sasse AD, Clark LG, Sasse EC et al. Amifostine reduces side effects and improves complete response rate during radiotherapy: Results of a meta-analysis. Int J Radiat Oncol Biol Phys 2006;64:784-791.

Savoye C, Swenberg C, Hugot S et al. Thiol WR-1065 and disulphide WR-33278, two metabolites of the drug ethyol (WR-2721), protect DNA against fast neutroninduced strand breakage. Int J Radiat Biol 1997;71:193-202.

Senzer N. A phase III randomized evaluation of amifostine in stage IIIA/IIIB non-small cell lung cancer patients receiving concurrent carboplatin, paclitaxel, and radiation therapy followed by gemcitabine and cisplatin intensification: Preliminary findings. Semin Oncol 2002;29:38-41. 
Shaw L, Brown W, Schein P et al. A phase I study comparing the relative bioavailability of intravenous (i.v.) and subcutaneous (s.c.) administration of amifostine (Ethyol). Proc Am Soc Clin Oncol 1997;16:250a.

Shaw LM, Turrisi AT, Glover DJ et al. Human pharmacokinetics of WR-2721. Int J Radiat Oncol Biol Phys 1986;12:1501-1504.

Shimizu S, Eguchi Y, Kamiike W et al. Induction of apoptosis as well as necrosis by hypoxia and predominant prevention of apoptosis by Bcl-2 and Bcl-XL. Cancer Res 1996;56:2161-2166.

Simone N, Menard C, Singh A. Intrarectal amifostine suspension may protect against acute proctitis during prostate radiation therapy: A pilot study. Presented at the Radiological Society of North America Annual Meeting; November 27-December 2; Chicago, IL, 2005.

Singh AK, Menard C, Guion P et al. Intrarectal amifostine suspension may protect against acute proctitis during radiation therapy for prostate cancer: A pilot study. Int J Radiat Oncol Biol Phys 2006;65:1008-1013.

Sonis ST, Fey EG. Oral complications of cancer therapy. Oncology (Williston Park) 2002;16:680-686, 691-692, 695; discussion 686.

Stone HB, Coleman CN, Anscher MS et al. Effects of radiation on normal tissue: Consequences and mechanisms. Lancet Oncol 2003;4:529-536.

Travis EL. The oxygen dependence of protection by aminothiols: Implications for normal tissues and solid tumors. Int J Radiat Oncol Biol Phys 1984;10:1495-1501.

Utley JF, Seaver N, Newton GL et al. Pharmacokinetics of WR-1065 in mouse tissue following treatment with WR-2721. Int J Radiat Oncol Biol Phys 1984;10:1525-1528.

Vacha P, Fehlauer F, Mahlmann B et al. Randomized phase III trial of postoperative radiochemotherapy +/- amifostine in head and neck cancer. Is there evidence for radioprotection? Strahlenther Onkol 2003;179:385-389.

Wagner W, Prott FJ, Schonekas KG. Amifostine: A radioprotector in locally advanced head and neck tumors. Oncol Rep 1998;5:1255-1257.

Washburn LC, Rafter JJ, Hayes RL. Prediction of the effective radioprotective dose of WR2721 in humans through an interspecies tissue distribution study. Radiat Res 1976;66:100-105.

Wasserman TH, Brizel DM, Henke $\mathrm{M}$ et al. Influence of intravenous amifostine on xerostomia, tumor control, and survival after radiotherapy for head-and-neck cancer: 2-year follow-up of a prospective, randomized, phase III trial. Int J Radiat Oncol Biol Phys 2005;63:985-990.

Yuhas JM, Spellman JM, Culo F. The role of WR-2721 in radiotherapy and/or chemotherapy. Cancer Clin Trials 1980;3:211-216.

Yuhas JM, Storer JB. Differential chemoprotection of normal and malignant tissues. J Natl Cancer Inst 1969;42:331-335.

Yuhas JM. Active versus passive absorption kinetics as the basis for selective protection of normal tissues by S-2-(3-aminopropylamino)-ethylphosphorothioic acid. Cancer Res 1980;40:1519-1524. 




\author{
Modern Practices in Radiation Therapy \\ Edited by Dr. Gopishankar Natanasabapathi
}

ISBN 978-953-51-0427-8

Hard cover, 370 pages

Publisher InTech

Published online 30, March, 2012

Published in print edition March, 2012

Cancer is the leading cause of death in economically developed countries and the second leading cause of death in developing countries. It is an enormous global health encumbrance, growing at an alarming pace. Global statistics show that in 2030 alone, about 21.4 million new cancer cases and 13.2 million cancer deaths are expected to occur, simply due to the growth, aging of the population, adoption of new lifestyles and behaviors. Amongst the several modes of treatment for cancer available, Radiation treatment has a major impact due to technological advancement in recent times. This book discusses the pros and cons of this treatment modality. This book "Modern Practices in Radiation Therapy" has collaged topics contributed by top notch professionals and researchers all around the world.

\title{
How to reference
}

In order to correctly reference this scholarly work, feel free to copy and paste the following:

Vassilis E. Kouloulias and John R. Kouvaris (2012). The Cytoprotective Effect of Amifostine Against Radiation Induced Toxicity, Modern Practices in Radiation Therapy, Dr. Gopishankar Natanasabapathi (Ed.), ISBN: 978953-51-0427-8, InTech, Available from: http://www.intechopen.com/books/modern-practices-in-radiationtherapy/the-cytoprotective-effect-of-amifostine-against-radiation-induced-toxicity-

\section{INTECH}

open science | open minds

\section{InTech Europe}

University Campus STeP Ri Slavka Krautzeka 83/A 51000 Rijeka, Croatia Phone: +385 (51) 770447 Fax: +385 (51) 686166 www.intechopen.com

\author{
InTech China \\ Unit 405, Office Block, Hotel Equatorial Shanghai \\ No.65, Yan An Road (West), Shanghai, 200040, China \\ 中国上海市延安西路65号上海国际贵都大饭店办公楼 405 单元 \\ Phone: $+86-21-62489820$ \\ Fax: +86-21-62489821
}


(C) 2012 The Author(s). Licensee IntechOpen. This is an open access article distributed under the terms of the Creative Commons Attribution 3.0 License, which permits unrestricted use, distribution, and reproduction in any medium, provided the original work is properly cited. 